\title{
POLNÍ OPEVNĚNÍ U JAROMĚŘE ZA VÁLKY O BAVORSKÉ DĚDICTVÍ (1778-1779). OBRANA STRATEGICKÉHO PROSTORU NA SOUTOKU LABE, METUJE A ÚPY PŘED STAVBOU PEVNOSTI PLES/JOSEFOV
}

\author{
PAVEL DRNOVSKÝ - PETR HEJHAL - LADISLAV RYTÍŘ
}

\begin{abstract}
Abstrakt: Území severovýchodních Čech se stalo v průběhu vlády Marie Terezie jedním z hlavních dějišt' prusko-rakouských konfliktü. Ze strategického hlediska byl důležitý zejména prostor vymezený městy Hradcem Králové a Jaroměři. Pruský král Fridrich toto územi pravidelně využival během přesunu svých vojsk při vpádech na území habsburské monarchie či při cestách zpět na územi Kladska a Horního Slezska. Během války o bavorské dèdictví rakouské veleni vybudovalo pás polních opevnění, který pruskému vojsku znemožnil proniknout dále do vnitrozemí. Úspěšnost této taktiky měla za následek modernizaci královéhradecké pevnosti a zbudování nové pevnosti Ples/Josefov. Článek se věnuje archeologickému poznání pásu polnich opevněni ve strategickém prostoru na soutoku Labe, Metuje a Úpy.
\end{abstract}

Klíčová slova: válka o bavorské dědictví-1778-1779-polní opevnění - fortifikace-východní Čechy.

Field fortifications near Jaroměr during the War of the Bavarian Succession (1778-1779). Defence of a strategic area at the confluence of the Elbe, the Metuje and the Úpa rivers before the construction of the Ples/Josefov fortress

Abstract: The territory of north-eastern Bohemia became in the course of the reign of Empress Maria Theresa one of the key locations of the Prussian-Austrian military conflict. In terms of strategy, an area demarcated by Hradec Králové and Jaroměr was particularly important. Prussian King Frederick regularly used this area for the redeployment of his armies during invasions to the Habsburg monarchy or on the journeys back to Glatz and Upper Silesia. During the War of the Bavarian Succession, the Austrians built a belt of field fortifications which made it impossible for the Prussian army to venture further into the country. The success of this tactics resulted in the modernization of the Hradec Králove fortress and in the construction of a new one called Ples/Josefov. The article discusses the archaeological research into the belt of field fortifications in the strategic area defined by the confluence of the Elbe, the Metuje and the Úpa rivers.

Key words: War of the Bavarian Succession - 1778-1779 - field fortifications - fortification - eastern Bohemia.

\section{1 Úvod}

Válka o bavorské dědictví, probíhající v letech 1778 a 1779, přinesla do té doby v habsburské monarchii nevídané nasazení polních opevnění, budovaných proti útoku sasko-pruské armády v severních a východních Čechách. ${ }^{1}$ Specifické místo v rámci opevněné linie tvořila oblast Jaroměře jako pomyslný severovýchodní vstup do Polabí. Vojenský význam tohoto prostoru byl roku 1780 potvrzen položením základního kamene nové pevnosti Ples/Josefov.

Morfologii terénu okolí Jaroměře určuje soutok tř́ řek - Labe, Metuje a Úpy. Řeka Labe tvoří osu oblasti a zároveň i přirozenou přírodní překážku ve směru sever-jih. Nebot' zatímco levý (východní) labský břeh se plynule zvedá do Novopleské plošiny, tak pravý (západní) břeh je tvořen výše položenými labskými terasami navazujícími na Velichovickou plošinu. Strategické polohy převážně na pravém labském břehu se staly místy pro vybudování jednotlivých polních opevnění.

1 Následující text je součástí dlouhodobého projektu, který se věnuje archeologickému výzkumu událostí války o bavorské dědictví (Drnovský-Hejhal 2018; v tisku; Hejhal-Hornik 2017). 


\section{Strategický význam sledované oblasti v kontextu válečných událostí 18. století}

\subsection{První a druhá slezská válka (1740-1745), válka sedmiletá (1756-1763)}

Vzhledem ke svému umístění představoval zkoumaný prostor důležitý komunikační koridor na severovýchodní hranici českého Polabí (obr. 1). Díky prŕírodním danostem tu procházela dálková cesta vedoucí od Hradce Králové na Jaroměř a pokračující dále na Náchod či Trutnov, tedy směrem umožňujícím spojení se sousedním Kladskem a Horním Slezskem. V souvislosti s novověkými válečnými operacemi lze zmínit již období let 1639-1646, kdy tento prostor několikrát využilo švédské vojsko k výpadům do východních Čech (Mertlíková-Č́ížek 2004; Žákovský-Drnovský 2017, 290-291). Daleko podstatnějšími se však staly události spojené s prusko-rakouským soupeřením během 18. století. Již v počáteční fázi první slezské války se pruský král Fridrich II. rozhodl po úspěšné anexi Slezska porušit mírovou dohodu s Marií Terezií a ke konci října 1741 vtáhl s armádou do Kladska. Již 1. listopadu pruské jednotky, které přišly přes Náchod, obsadily Českou Skalici a o dva dny později se zmocnily Hradce Králové. Králova armáda

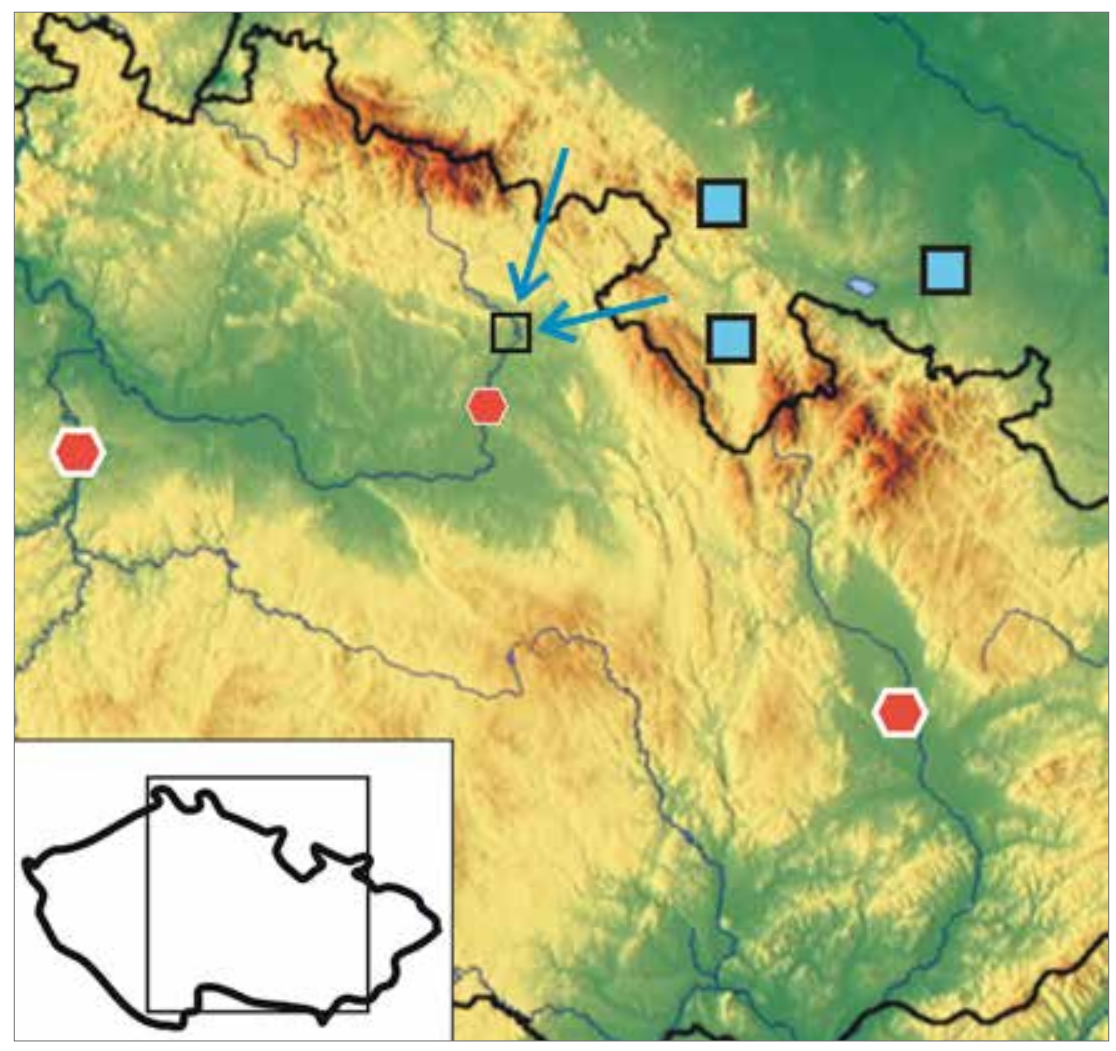

Obr. 1. Sledovaná oblast v kontextu válečných událostí 18. století. Polygony představují exponované opěrné body habsburské armády (Praha, Hradec Králové, Olomouc). Čtverce označují pruské opěrné body získané a vybudované po anexi Kladska a Slezska (Kladsko, Nisa, Stříbrná Hora). Šipky ukazují směr pruských vpádů do prostoru východních Čech. Jaroměřsko označeno prázdným obdélníkem.

Abb. 1. Beobachtetes Gebiet im Kontext der Kriegsereignisse des 18. Jahrhunderts. Die Polygone stellen exponierte Stützpunkte der habsburgischen Armee dar (Prag, Königgrätz, Olmütz). Die Quadrate kennzeichnen die nach der Annexion von Glatz und Schlesien (Glatz, Neisse, Silberberg) eingenommenen und errichteten Stützpunkte. Die Pfeile zeigen die Richtung der preußischen Einfälle in den ostböhmischen Raum. Die Region Jaroměř ist mit einem leeren Rechteck gekennzeichnet. 
pak úspěšně operovala (bitva u Chotusic) v českých zemích podporujíc protihabsburské spojence až do poloviny roku 1742, kdy po uzavření míru s Rakouskem stáhl Fridrich své jednotky zpět (Duffy 1985, 28-45). Pruské vojsko vtrhlo bez řádného vyhlášení války do Čech opět v roce 1744, kdy chtěl Fridrich II. pojistit zisk nabytých území a zastavit rakouskou úspěšnou ofenzívu na Rýně. Jeden ze tří pruských proudů pod velením maršála Schwerina opět přešel z Kladska na Náchod a 17. srpna přes Jaroměř a pokračoval dále k Hradci. Po seskupení vojsk pak Fridrich úspěšně oblehl a dobyl Prahu. Toutéž cestou pak táhl v čele vojska pruský král na konci listopadu roku 1744 zpět do Slezska (Duffy 1985, 51-56). Po prohrané bitvě u Hohenfriedebergu v červnu 1745 se spojená rakousko-saská vojska stáhla až k Hradci Králové. Pronásledující pruská armáda pod velením Fridricha II. se pak opět bez odporu přes Jaroměř dostala až do prostoru severně a západně od Hradce. Tyto pozice pak byly Prusy vyklizeny až v záŕí téhož roku, kdy se stáhly zpět za hranice království (Hosák 1964). Těmito událostmi pro sledované území skončila přímá konfrontace s pohyby cizích vojsk, nebot' v prosinci uzavřený mír znamenal konec vojenských operací na středoevropském bojišti, tzv. válek o rakouské dědictví (Maur 2003, 21).

Již během prvního roku sedmileté války opět vtrhla pruská vojska do Čech. Do východních Čech pronikla část pruské armády pod velením maršála Schwerina v polovině záŕí 1756. Po průchodu Jaroměří se utábořila severovýchodně od Hradce Králové. V tomto prostoru pak operovala až do 21. ř́ijna 1756, kdy se v reakci na vývoj v severních Čechách (bitva u Lovosic, situace v Sasku) stejnou cestou vrátila zpět do Kladska (Stellner 2000, 84-99). Znovu se pruská armáda pod velením krále Fridricha dostala do východních Čech po neúspěšném obléhání Olomouce $\mathrm{v}$ roce 1758 . Tentokrát však přitáhla $\mathrm{z}$ opačné strany a nejprve prošla přes Hradec (11. července) a teprve posléze dále na Jaroměř (26. července) zpět do Kladska (Duffy 1985, 160-161). Vzhledem $\mathrm{k}$ následnému přesunutí hlavních bojů mimo naše území již po zbytek sedmileté války zde nedošlo k průchodu hlavních pruských sil (Stellner 2000, 225-305). Nicméně od roku 1761 pronikaly z Kladska menší vojenské oddíly, které se vydávaly drancovat i hluboko do českého vnitrozemí. V červenci 1762 dokonce skupina pruských husarů nakrátko obsadila Hradec Králové, který byl následně silně poničen požárem (Mikulka 1994, 188-190).

Během několika válečných let tedy hlavní pruské síly pod vedením krále Fridricha II., nebo přinejmenším významná část pruského vojska použila průchod přes Jaroměř do Čech (a naopak), a to celkem devětkrát. Dále docházelo k řadě menších průjezdů nepřátelských vojsk. Tato otevřenost průchodu do centra Čech znamenala kromě přímého nebezpečí pro Hradec a Jaroměř i ohrožení nejúrodnějších částí Polabí (Knnap 1887, 168-175; Vojtíšková-Polehla 2017, 268273). Pruská armáda vniknutím do prostoru Hradce Králové získávala volný operační prostor k postupu na Prahu, či na Moravu. Dále ji tak bylo umožněno živit se ze zdrojů cizího území, čímž významně trpěla ekonomika obsazené části Čech. Tyto zkušenosti s nečekanými pruskými vpády vedly k odhodlání rakouského velení vybudovat pevnost, která by ochránila severovýchodní část Čech od podobných invazních plánů (Honl 1924; 1924a). V roce 1765 bylo rozhodnuto o vybudování bastionové zemní pevnosti v prostoru města Hradce Králové (Slavík 2015, 16).

\subsection{Válka o bavorské dědictví}

K poslednímu konfliktu mezi habsburskou monarchií a pruským královstvím došlo v roce 1778. Důvodem k válce bylo úmrtí posledního člena bavorské větve Wittelsbachů Maxmiliána Josefa v závěru roku 1777 a spor o řešení nástupnictví v Bavorsku. Pruský král projevil nesouhlas s rakouským řešením a 3. července vyhlásil válku, přičemž již o dva dny později překročil v čele svého vojska české hranice u Náchoda. Další seskupení prusko-saských sil pod velením Fridrichova bratra, prince Jindřicha, operovalo v prostoru severozápadních Čech. Rakouské velení se však na očekávanou invazi řádně připravilo a podařilo se blokovat obě pruské armády v př́ihraničních oblastech Čech. Vzhledem k rakouské taktice musel Fridrich II. tažení roku 1778 ukončit z důvodu výrazných logistických problémů svého vojska. Ačkoliv během tažení došlo jen k menším střetům a šarvátkám, ztráty na životech vojáků byly značné a vyžádaly si je zejména nemoci a dezerce (na pruské straně se udává 20000 ). Boje v menší intenzitě probíhaly ještě na 
přelomu let 1778 a 1779, nicméně již 13. května byl uzavřen těšínský mír, který ukončil veškeré bojové aktivity obou armád (Schmettau 1789; Duška 1886, 19-55; Honl 1925-1926; Duffy 1985, 263-278; Bělina-Kaše 2017, 185-200; Šedivý 2018).

\section{Lacyho linie a možnosti lokalizace objektů polních opevnění}

V rámci příprav na vojenský střet (a posléze i v jeho průběhu) byla ve východních Čechách od přelomu dubna a května 1778 budována linie polních opevnění táhnoucí se od Tří Bubnů u Chrudimi po Vrchlabí. Podle polního maršála Franze Morice Lacyho, který měl na jejím vzniku významný podíl, se tato linie nazývá Lacyho opevňovací systém, př́ípadně Lacyho linie. Opevnění mělo zásadní vliv na směr pohybu pruské armády a vlastně i neúspěch celého tažení roku 1778. Ve východních Čechách šlo o systém minimálně 167 objektů polních opevnění různých typů (základním pramenem k Lacyho linii je práce T. Peterse z roku 1902, nově s další literaturou např. Čížek-Slavík 2010 nebo Hejhal-Hornik 2017). Polní opevnění bylo budováno i na severu Čech (k severočeské části opevněné linie viz Nejman 2010).

Pramenů k objektům Lacyho opevňovacího systému je celá řada, ovšem ne všechny mají stejnou vypovídací hodnotu. Za základní zdroj informací pro naši práci považujeme listy

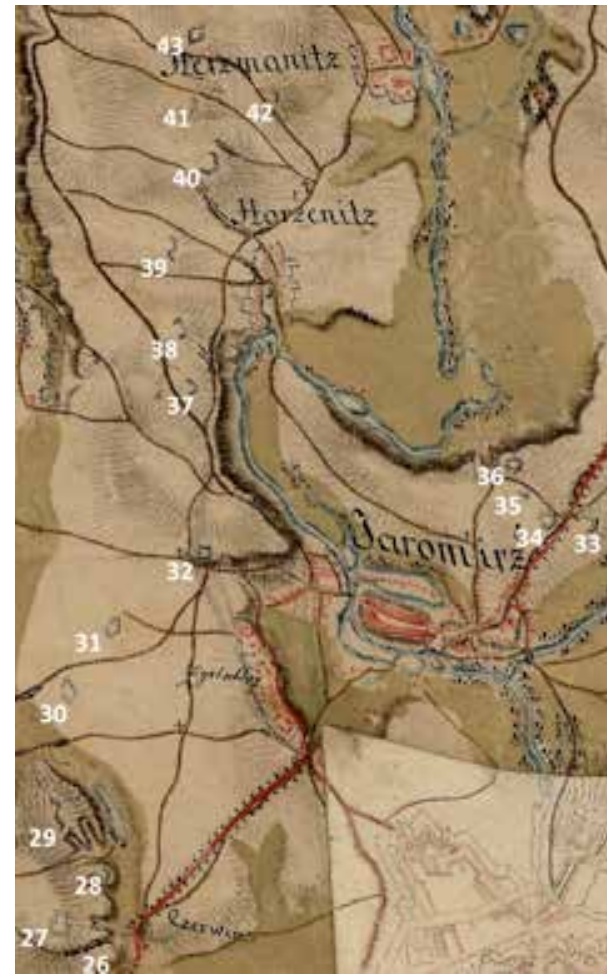

Obr. 2. Průběh Lacyho linie na mapovém listu 1. vojenského mapování. Čísla jednotlivých objektů polních opevnění odpovídají číslování v textu. Zdroj http://mapire.eu.

Abb. 2. Velauf der Lacy-Linie auf einem Kartenblatt der 1. militärischen Kartierung. Die Nummern der einzelnen Feldbefestigungsobjekte entsprechen der Nummerierung im Text. Quelle http://mapire.eu.

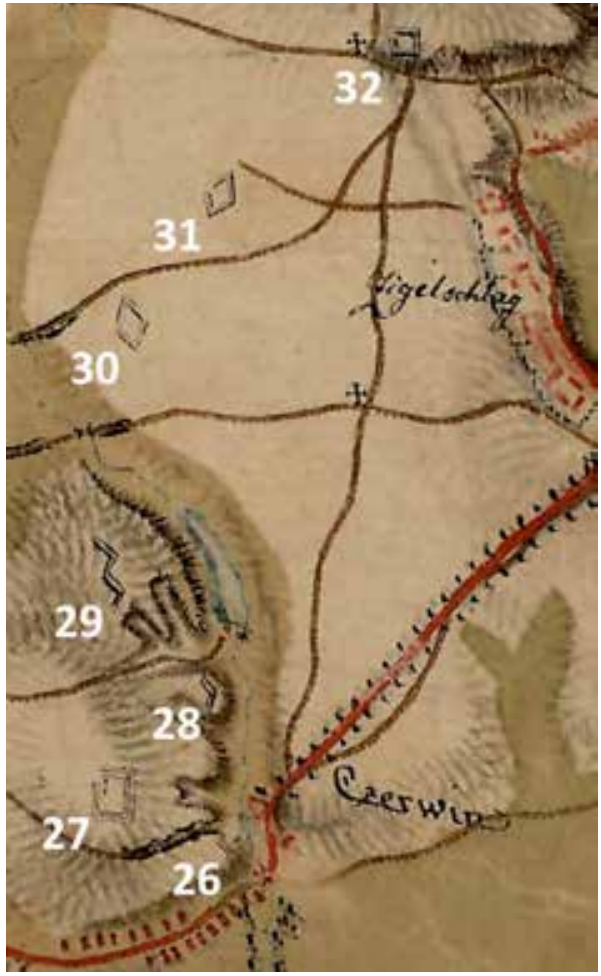

Obr. 3. Podrobný pohled na část Lacyho linie západně od Jaroměře na mapovém listu 1. vojenského mapování. Čísla jednotlivých objektů polních opevnění odpovídají číslování v textu. Zdroj http://mapire.eu.

Abb. 3. Detailansicht eines Teils der Lacy-Linie westlich von Jaroměr̆ auf einem Kartenblatt der 1. militärischen Kartierung. Die Nummern der einzelnen Feldbefestigungsobjekte entsprechen der Nummerierung im Text. Quelle http://mapire.eu. 


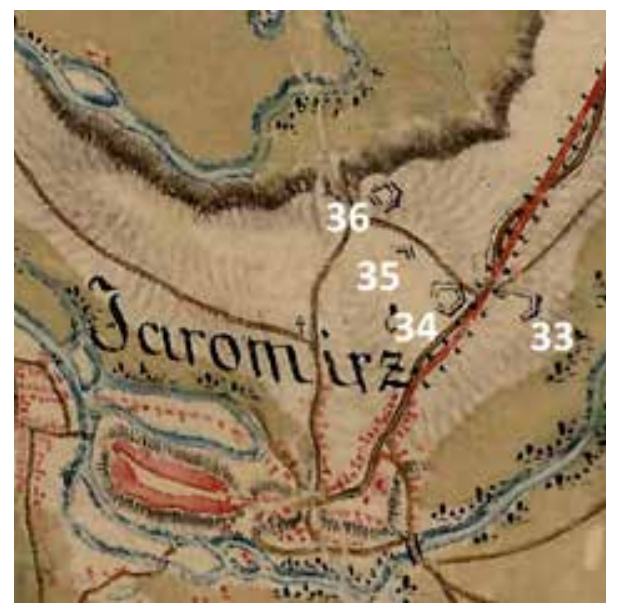

Obr. 4. Podrobný pohled na část Lacyho linie východně od Jaroměře na mapovém listu 1. vojenského mapování. Čísla jednotlivých objektů polních opevnění odpovídají číslování v textu. Zdroj http://mapire.eu.

Abb. 4. Detailansicht eines Teils der Lacy-Linie östlich von Jaroměř auf einem Kartenblatt der 1. militärischen Kartierung. Die Nummern der einzelnen Feldbefestigungsobjekte entsprechen der Nummerierung im Text. Quelle http:// mapire.eu.

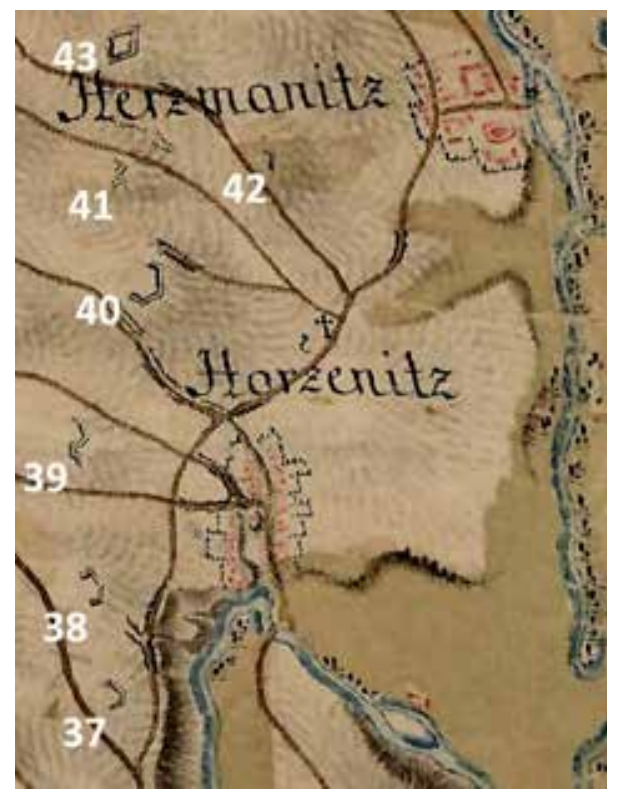

Obr. 5. Podrobný pohled na část Lacyho linie severně od Jaroměře na mapovém listu 1. vojenského mapování. Čísla jednotlivých objektů polních opevnění odpovídají číslování v textu. Zdroj http://mapire.eu.

Abb. 5. Detailansicht eines Teils der Lacy-Linie nördlich von Jaroměř auf einem Kartenblatt der 1. militärischen Kartierung. Die Nummern der einzelnen Feldbefestigungsobjekte entsprechen der Nummerierung im Text. Quelle http://mapire.eu.
1. vojenského mapování. Jeho důvěryhodnost, co se týče pozic a vzhledu polních opevnění z války o bavorské dědictví ve východních Čechách, byla opakovaně potvrzena prospekcemi v terénu, geofyzikálním měřením i studiem leteckých snímků. Rektifikace tohoto mapování na sledovaném území proběhla $\mathrm{v}$ roce 1780 setníkem Püschelem $\mathrm{z}$ důvodu špatně zachycené polohy vesnic. Toto dílo tak zachycuje východočeskou krajinu pouhé dva roky po skončení konfliktu. Zkoumaná oblast je zachycena na mapovém listu č. 79 (obr. 2-5).

Protože cílem naší práce je skutečně přesná lokalizace, považujeme polohu určenou pouze na základě 1 . vojenského mapování jen za přibližnou (ačkoli i zde je možné zaniklý objekt lokalizovat do kružnice o průměru 100 metrů). V některých případech jsou objekty polních opevnění zachyceny na 2 . vojenském mapování (mapový list 6/IX, na kterém jsou zachyceny objekty pojednávané $\mathrm{v}$ tomto článku, byl vytvořen $\mathrm{v}$ letech 1851-1852). Také vyobrazení objektů na 2 . vojenském mapování bereme jako přibližnou lokalizaci, kterou je nutné doplnit jiným zdrojem.

Mapovým zdrojem, který naopak považujeme $\mathrm{z}$ hlediska lokalizace za přesný, je stabilní katastr Jaroměře z roku 1840. Z dvaceti objektů ve sledované oblasti jich bylo na tomto mapovém díle zachyceno čtrnáct (obr. $9,14)$. V tomto př́ipadě nebyly často zachyceny kompletní objekty, někdy šlo pouze o jejich fragmenty nebo deformované půdorysy.

Ostatní prameny - ačkoli byly vytvořeny př́ímými účastníky událostí, př́ípadně byly pořízeny s kratším časovým odstupem od výstavby opevnění - pokládáme, co se týče přesnosti lokalizace sledovaných objektů, pouze za prameny doplňující a vždy je kombinujeme $\mathrm{s}$ některým $\mathrm{z}$ výše uvedených zdrojů. Jsou to hlavně plány tvořící součást pamětí Alberta Kazimíra, vévody Sasko-Těšínského ( $\mathrm{Me}$ moires sur la Campagne de 1778 en Bohéme et Moravie; dostupné na http://manuscriptorium.com) a mapa pruského generála Friedricha Wilhelma Carla von Schmettau (Topographische und Militairische Carte desjenigen Theils von Bxhmen welcher zwischen Hohenelbe, Pless und der Schlesischen Grentze gelegen ist. Nebst denen Loegern von der Campagne 1778 , k tomuto prameni detailně Iša 2006). 


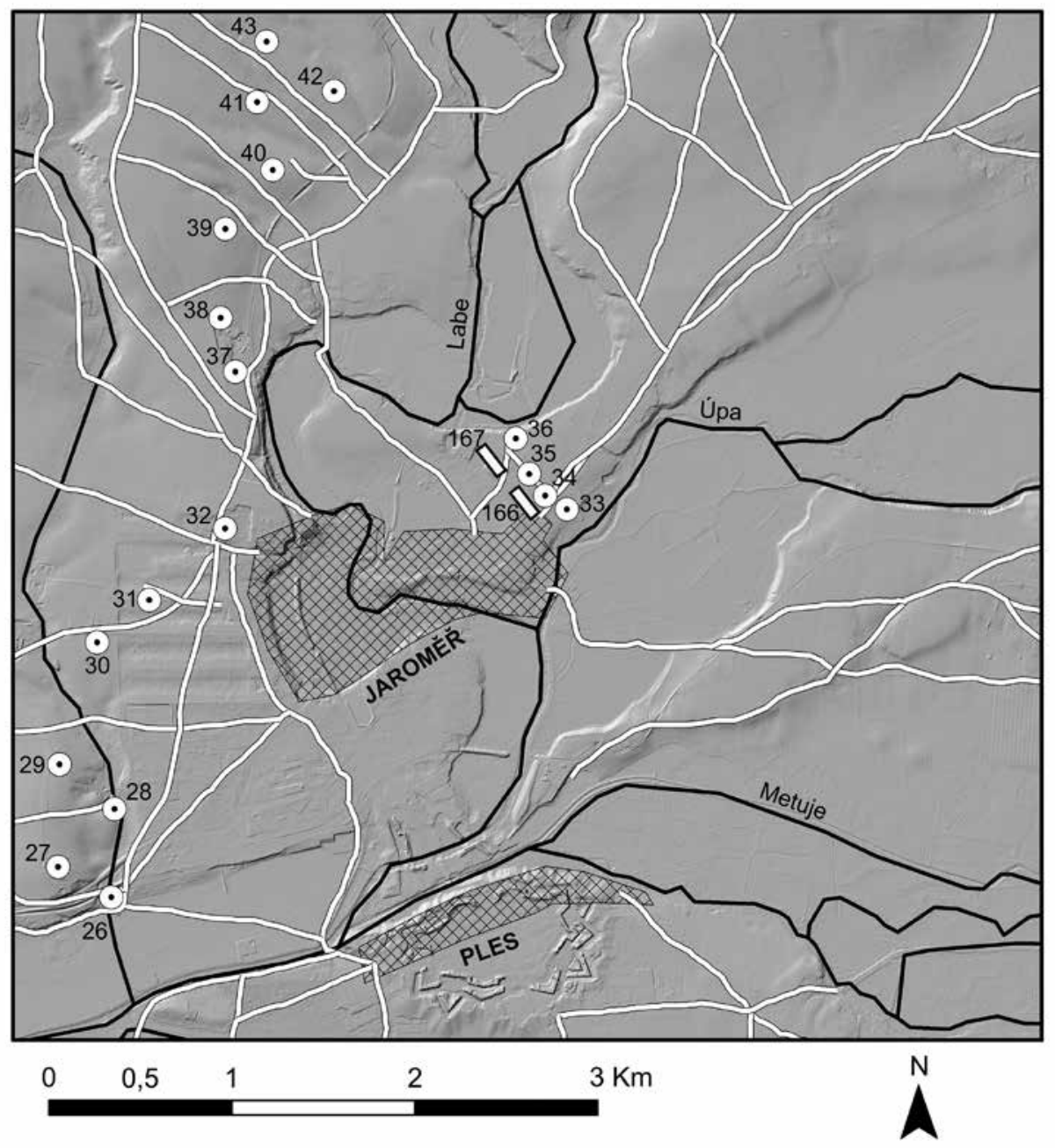

Obr. 6. Lokalizace objektů Lacyho linie s intravilány obcí, vodními toky a komunikační sítí převzatou z 1. vojenského mapování. Jako podklad je použit veřejně př́stupný digitální model reliéfu 5. generace. Zdroj http://ags.cuzk.cz.

Abb. 6. Lokalisierung der Objekte der Lacy-Linie mit Innenbereich der Gemeinden, mit Wasserläufen und dem Verkehrswegenetz. Entnommen aus der 1. militärischen Kartierung. Als Vorlage diente ein öffentlich zugängliches digitales Reliefmodell der 5. Generation. Quelle http://ags.cuzk.cz.

K upřesnění informací získaných z mapových pramenů využíváme postupy archeologické. Ty zahrnují terénní prospekce, vyhledávání a zaměřování terénních reliktů pomocí GPS nebo totální stanice, studium leteckých snímků, ${ }^{2}$ geofyzikální prospekce a případně archeologický výzkum (obr. 7, 12).

\section{Objekty polních opevnění - katalog}

V následujícím katalogu používáme pro stupeň přesnosti lokalizace objektů dvě kategorie: „přesná lokalizace“ a „přibližná lokalizace“. Přesná lokalizace znamená, že je splněno

2 V současné době používáme pouze volně dostupné letecké snímky. 


\begin{tabular}{|c|c|c|c|c|c|c|c|c|}
\hline $\begin{array}{c}\text { číslo } \\
\text { objektu }\end{array}$ & $\begin{array}{l}\text { přesnost } \\
\text { lokalizace }\end{array}$ & 1. voj. map. & 2. voj. map. & $\begin{array}{c}\text { stab. } \\
\text { katastr }\end{array}$ & $\begin{array}{l}\text { zachovanost } \\
\text { v terénu }\end{array}$ & $\begin{array}{l}\text { porostové } \\
\text { příznaky }\end{array}$ & geofyzika & $\begin{array}{l}\text { arch. } \\
\text { výzkum }\end{array}$ \\
\hline 26 & přibližné & redan & $\mathrm{NE}$ & $\mathrm{NE}$ & $\mathrm{NE}$ & $\mathrm{NE}$ & $\mathrm{NE}$ & $\mathrm{NE}$ \\
\hline 27 & přesné & reduta & ANO & ANO & ANO & ANO & $\mathrm{NE}$ & $\mathrm{NE}$ \\
\hline 28 & přibližné & redan & NE & NE & NE & $\mathrm{NE}$ & $\mathrm{NE}$ & NE \\
\hline 29 & přesné & biret & ANO & ANO & ANO & ANO & $\mathrm{NE}$ & $\mathrm{NE}$ \\
\hline 30 & př̌ibližné & reduta & $\mathrm{NE}$ & $\mathrm{NE}$ & NE & NE & NE & $\mathrm{NE}$ \\
\hline 31 & přesné & reduta & NE & NE & NE & ANO & NE & NE \\
\hline 32 & přesné & reduta & $\mathrm{NE}$ & ANO & $\mathrm{NE}$ & $\mathrm{NE}$ & $\mathrm{NE}$ & $\mathrm{NE}$ \\
\hline 33 & přesné & luneta & ANO & ANO & $\mathrm{NE}$ & $\mathrm{NE}$ & $\mathrm{NE}$ & $\mathrm{NE}$ \\
\hline 34 & presné & $\begin{array}{c}\text { reduta } \\
\text { pětiboká }\end{array}$ & ANO & ANO & $\mathrm{NE}$ & $\mathrm{NE}$ & $\mathrm{NE}$ & $\mathrm{NE}$ \\
\hline 35 & přesné & redan & ANO & ANO & $\mathrm{NE}$ & NE & NE & $\mathrm{NE}$ \\
\hline 36 & přesné & $\begin{array}{c}\text { reduta } \\
\text { šestiboká }\end{array}$ & ANO & ANO & $\mathrm{NE}$ & $\mathrm{NE}$ & $\mathrm{NE}$ & $\mathrm{NE}$ \\
\hline 37 & přesné & luneta & NE & ANO & $\mathrm{NE}$ & NE & $\mathrm{NE}$ & $\mathrm{NE}$ \\
\hline 38 & přesné & luneta & ANO & ANO & $\mathrm{NE}$ & $\mathrm{NE}$ & $\mathrm{NE}$ & $\mathrm{NE}$ \\
\hline 39 & přesné & $\begin{array}{l}\text { luneta } \\
\text { s valem }\end{array}$ & ANO & $\mathrm{NE}$ & NE & NE & ANO & ANO \\
\hline 40 & přesné & luneta & ANO & ANO & $\mathrm{NE}$ & NE & NE & $\mathrm{NE}$ \\
\hline 41 & přesné & biret & ANO & ANO & $\mathrm{NE}$ & ANO & NE & NE \\
\hline 42 & přibližné & redan & NE & NE & $\mathrm{NE}$ & NE & NE & $\mathrm{NE}$ \\
\hline 43 & přesné & reduta & $\mathrm{NE}$ & ANO & $\mathrm{NE}$ & ANO & $\mathrm{NE}$ & $\mathrm{NE}$ \\
\hline 166 & přesné & $\mathrm{NE}$ & NE & ANO & $\mathrm{NE}$ & $\mathrm{NE}$ & NE & NE \\
\hline 167 & přesné & NE & $\mathrm{NE}$ & ANO & $\mathrm{NE}$ & NE & $\mathrm{NE}$ & $\mathrm{NE}$ \\
\hline
\end{tabular}

Tab. 1. Přehled sledovaných atributů jednotlivých objektů polních opevnění Lacyho linie ve sledovaném prostoru.

Tab. 1. Übersicht der beobachteten Attribute der einzelnen Feldbefestigungsobjekte der Lacy-Linie im untersuchten Bereich.

minimálně jedno z následujících kritérií: existují nadzemní části objektu (nebo jeho části), objekt byl zkoumán archeologicky, objekt je viditelný na leteckých snímcích, objekt byl zachycen geofyzikálním měřením, objekt je zakreslen na stabilním katastru. Uvedené GPS souřadnice jsou umístěny do interiéru objektu. Přibližná lokalizace znamená, že na základě 1. a (nebo) 2. vojenského mapování je možné objekt lokalizovat do kružnice o průměru 100 metrů. Uvedené GPS souřadnice jsou v těchto př́ípadech umístěny přibližně do středu této kružnice.

Při číslování objektů navazujeme na číselnou řadu použitou v článku věnujícím se nejjižnější části Lacyho opevňovacího systému (Hejhal-Hornik 2017).

\section{Obj. 26, k. ú. Jezbiny - přibližná lokalizace}

Na 1. vojenském mapování je zakreslen redan, hrotem směřující k východu. Objekt je umístěn na západní hraně nivy Jezbinského potoka. Severně je plocha redanu vymezena cestou ústící do nivy Jezbinského potoka, na jihu redan nezasahuje do prostoru zástavby obce Jezbiny. Terén je v tomto prostoru výrazně narušen železniční tratí Hradec Králové - Jaroměř a silnicí $\mathrm{I} / 33$. Původně se zde nacházela ostrožna s hranami spadajícími k východu a k jihu, která je patrná ještě na 2. vojenském mapování. Vzhledem $\mathrm{k}$ výše uvedeným orientačním bodům se opevnění pravděpodobně nacházelo v okolí bodu $50^{\circ} 20^{\prime} 18.544^{\prime \prime} \mathrm{N}, 15^{\circ} 53^{\prime} 55.729^{\prime \prime E}$. V současné době je můžeme pokládat s největší pravděpodobností za zničené, nejspíš stavbou železniční trati 031 Pardubice - Hradec Králové - Jaroměř. 

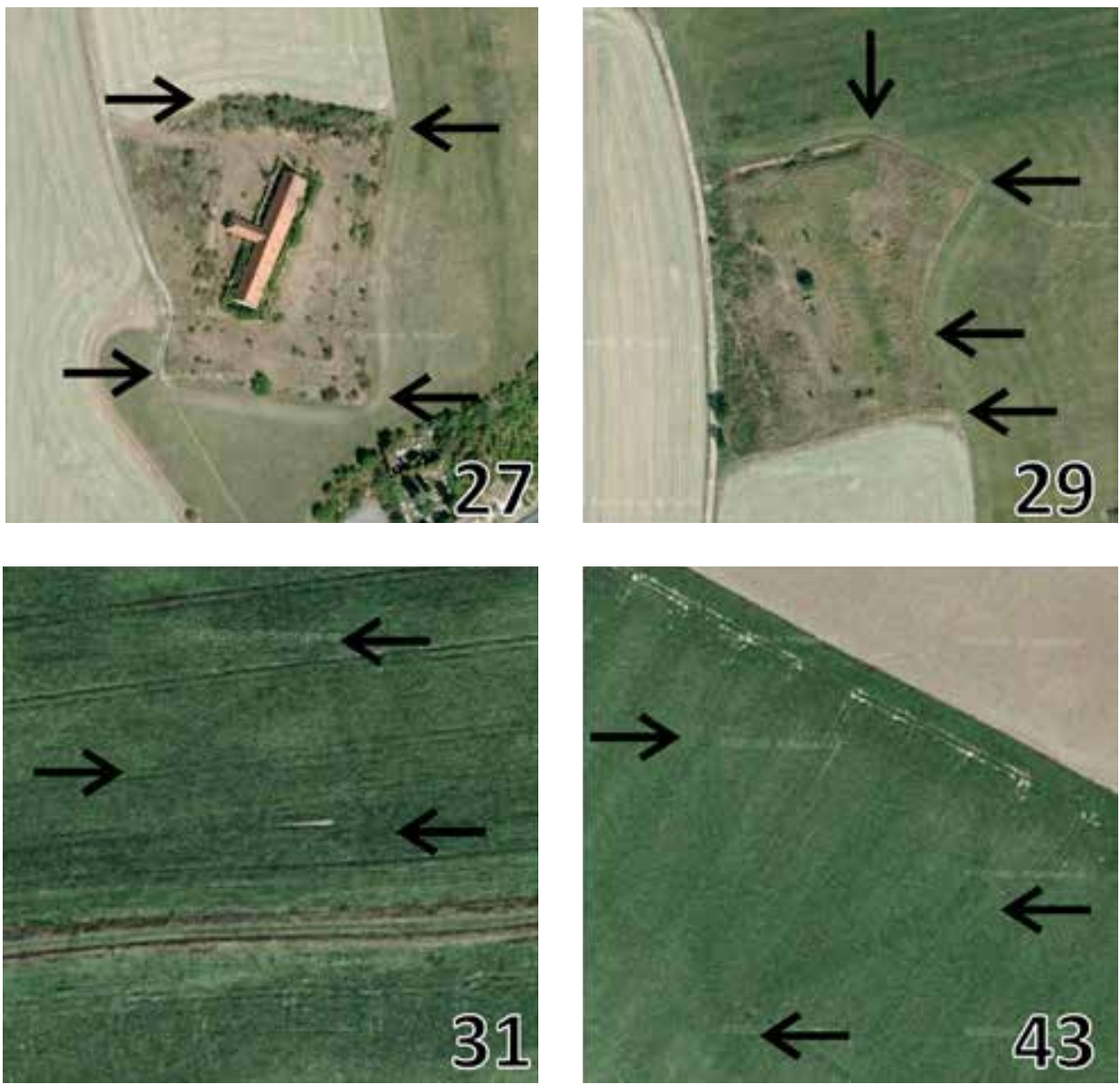

Obr. 7. Příklady dochovaní objektů polních opevnění v terénních reliktech a vegetačních projevech na leteckých snímcích. Číslo v pravém dolním rohu odpovídá číslování v textu. Zdroj http://mapy.cz.

Abb. 7. Beispiele für erhalten gebliebene Feldbefestigungsobjekte in Geländerelikten und Vegetationsausprägungen auf Luftaufnahmen. Die Nummer in der rechten unteren Ecke entspricht jeweils der Nummerierung im Text. Quelle http:// mapy.cz.

Obj. 27, k. ú. Jaroměr

Na 1. vojenském mapování je zakreslena reduta. Lokalizace objektu je bezproblémová, nebot' objekt je v terénu velmi dobře dochován (obr. 7, 8). Reduta je obdélného půdorysu, s delší osou orientovanou ve směru sever-jih. Půdorys objektu má přibližné rozměry $140 \times 90$ metrů (včetně dnes již zasypaných př́íkopů). Vstup do reduty byl v jejím severozápadním nároží. Střed opevnění: 50²0'23.359"N, 1553'45.330"E.

Objekt reduty byl využit při stavbě josefovské pevnosti pro umístění jedné z mírových pracháren a pravděpodobně díky tomu je zachován dodnes. Stavba pracháren na Libině byla ukončena roku 1788 (Duška 1886, 161).

Obj. 28, k. ú. Jaroměr

$\mathrm{Na}$ 1. vojenském mapování je zakreslen redan, hrotem směřující $\mathrm{k}$ východu. Objekt je umístěn na jazykovité ostrožně nad pravém (západním) břehu nivy Jezbinského potoka, 


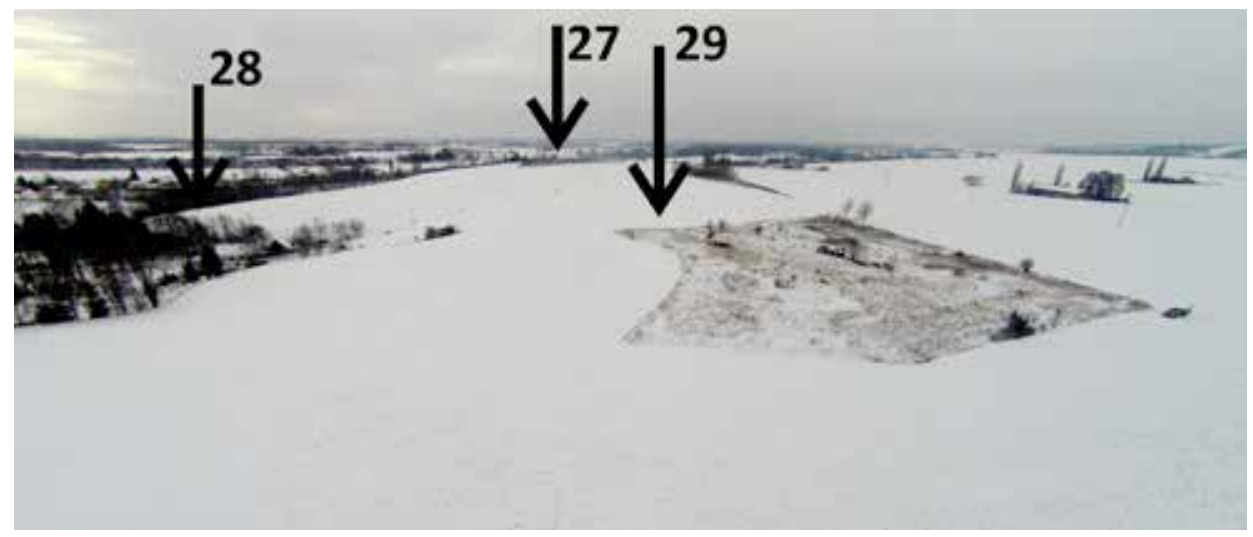

Obr. 8. Letecký snímek objektu č. 29 (biret), k. ú. Dolní Dolce, leden 2018. Opevnění z války o bavorské dědictví bylo ve svém týlu doplněno a uzavřeno př́ikopem v souvislosti s budováním jedné z pracháren josefovské pevnosti. Část půdorysu biretu je dobře patrná ve východní části objektu (na snímku levá část objektu). Šipkami označeny sousední objekty č. 28 (redan, nedochovaný) a 27 (reduta, dochovaná).

Abb. 8. Luftaufnahme von Objekt Nr. 29 (Flesche), Katastergebiet Dolní Dolce. Januar 2018. Die aus dem bayerischen Erbfolgekrieg stammende Befestigung wurde in ihrem Hinterland im Zusammenhang mit dem Bau eines der Pulvermagazine der Festung Josefstadt um einem Graben ergänzt und von ihm abgeschlossen. Ein Teil des Grundrisses der Flesche ist im östlichen Teil des Objektes (auf der Aufnahme der linke Teil des Objektes) gut erkennbar. Mit Pfeilen gekennzeichnet sind die Nachbarobjekte Nr. 28 (Redan, nicht erhalten geblieben) und Objekt Nr. 27 (Redoute, erhalten geblieben).

severovýchodně od objektu 27 a jihovýchodně od objektu 29. Redan byl vybudován jižně od komunikace vycházející z hráze Doleckého rybníka a pokračující na západ. Nadzemní část objektu není dochována. Objekt není zachycen na vojenském mapování ani na stabilním katastru. Na volně dostupných leteckých snímcích nebylo opevnění dosud dohledáno. Můžeme ho lokalizovat do okolí bodu $50^{\circ} 20^{\prime} 35.228^{\prime \prime} \mathrm{N}, 15^{\circ} 53^{\prime} 54.508^{\prime \prime} \mathrm{E}$.

\section{Obj. 29, k. ú. Jaroměr - presná lokalizace}

Na 1. vojenském mapování je zakreslen biret. Hroty biretu směřují k východu, směrem $\mathrm{k}$ údolí Jezbinského potoka, respektive v tomto místě Doleckého rybníka. Lokalizace je v tomto případě velmi přesná, podstatná část objektu existuje ve formě nadzemních reliktů (obr. 7, 8). Stejně jako u objektu č. 27 i v tomto př́ípadě došlo k využití opevnění z války o bavorské dědictví k umístění josefovské mírové prachárny. Za tímto účelem byl biret na své severní, západní a jižní straně uzavřen př́íkopem. Na základě dochovaných reliktů můžeme původní vzdálenost mezi nejvzdálenějšími body ramen biretu odhadovat na 150 metrů (včetně příkopů). Přibližný střed opevnění je okolo bodu $50^{\circ} 20^{\prime} 41.501 " \mathrm{~N}, 15^{\circ} 53^{\prime} 42.529 " \mathrm{E}$.

\section{Obj. 30, k. ú. Jaroměr - přibližná lokalizace}

Na 1. vojenském mapování je zakreslena reduta kosočtverečného půdorysu s orientací delší osy ve směru severoseverozápad-jihojihovýchod. Vstup do objektu byl v místě jeho západního nároží. Objekt byl umístěn nad nivou Jezbinského potoka (na jeho levém, východním břehu), jižně od cesty směřující z Jaroměře na návrší Libiny. Nadzemní část objektu není dochována. Velmi pravděpodobně se objekt nacházel v okolí bodu 50²1'3.700"N, 1553'48.951"E.

\section{Obj. 31, k. ú. Jaroměr - přesná lokalizace}

$\mathrm{Na}$ 1. vojenském mapování je zakreslena reduta kosočtverečného půdorysu s orientací delší osy ve směru severoseverovýchod-jihojihozápad. Vstup do objektu byl v místě jeho západního nároží. Nadzemní část objektu není dochována. Severní část objektu je dobře patrná na leteckém snímku z roku 2006 (obr. 7). Severní roh objektu je v bodu 50²1'14.322"N, 1554'4.130"E. Na 


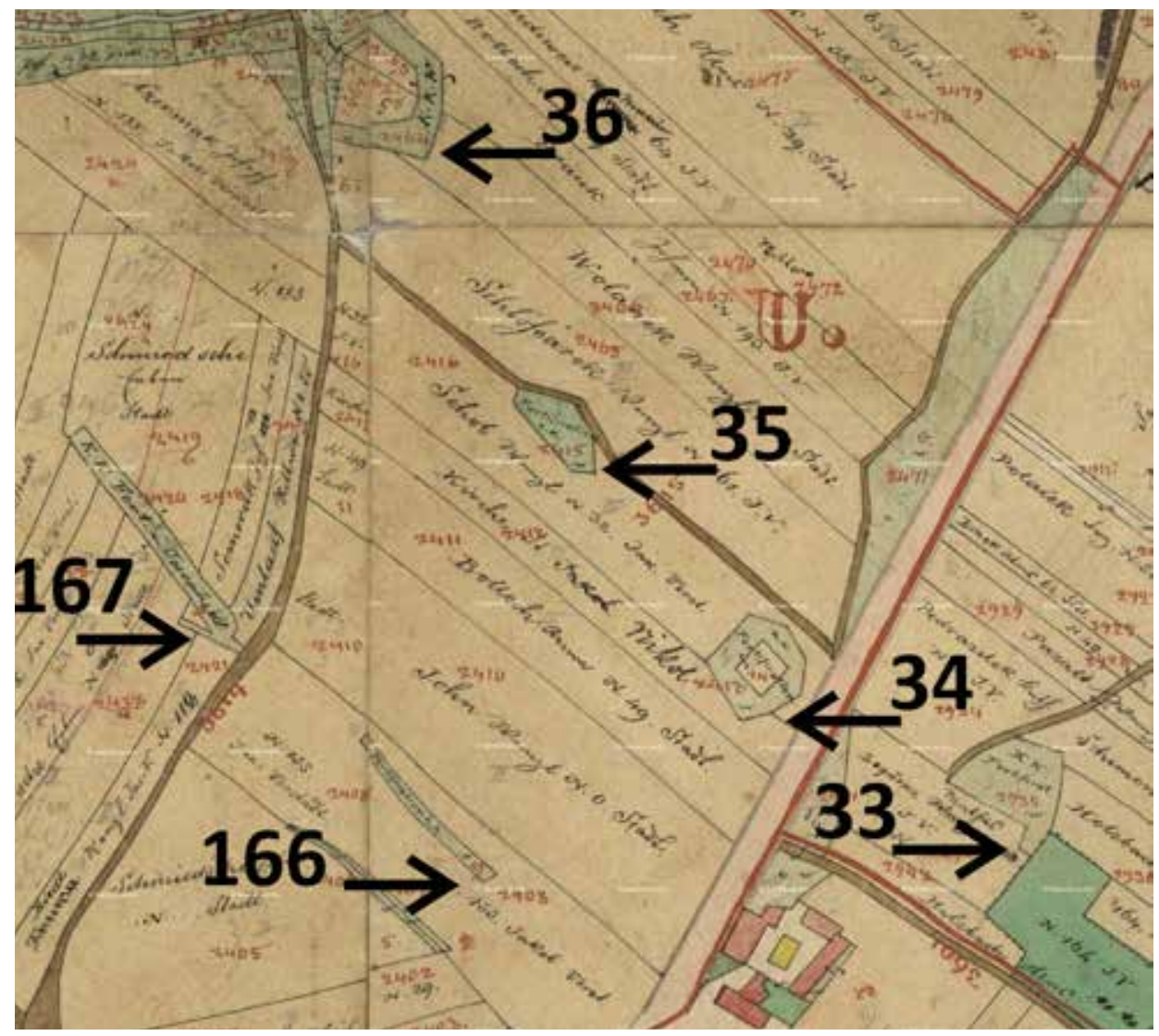

Obr. 9. Relikty objektů polních opevnění v prostoru Jakubského předměstí východně od Jaroměře zachycené na Indikační skice stabilního katastru, 1840. Zdroj https://archivnimapy.cuzk.cz; @ Č́́ZK.

Abb. 9. Relikte der Feldbefestigungsobjekte in der Jakobi-Vorstadt östlich von Jaroměř dargestellt auf einer Indikationsskizze des stabilen Katasters, 1840. Quelle https://archivnimapy.cuzk.cz; ( Tschechischces Amt für Landesvermessung und Kataster.

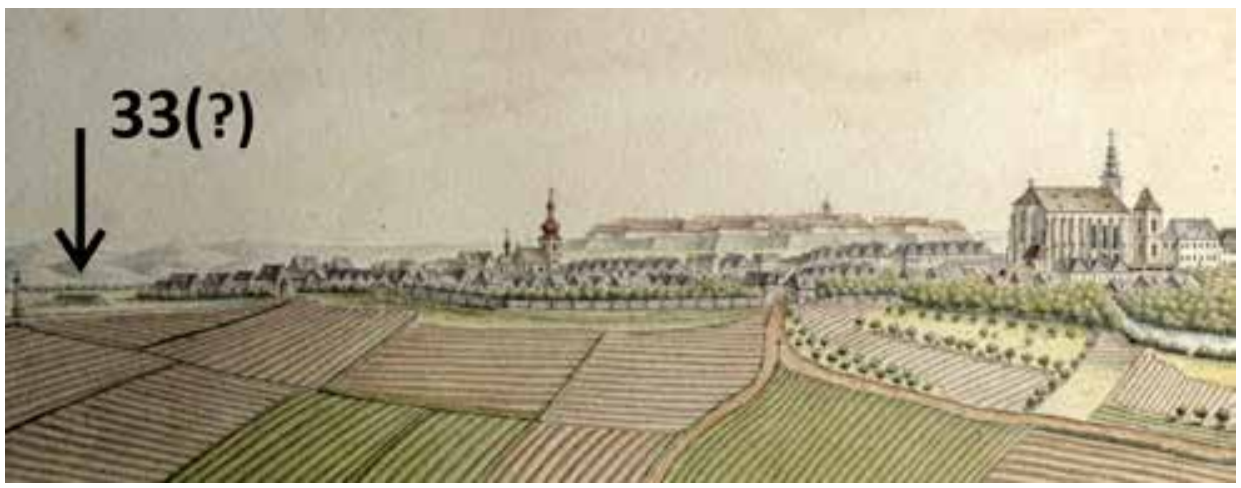

Obr. 10. Objekt polního opevnění (patrně č. 33) na vedutě Jaroměře J. Venuta z roku 1809. Podle Veselý $2018,107$.

Abb. 10. Feldbefestigungsobjekt (offenbar Nr. 33) auf einer Stadtansicht von Jaroměř von Johann Venuto aus dem Jahr 1809. Nach Veselý 2018, 107. 
základě leteckého snímku lze stanovit délku viditelných částí severovýchodního a severozápadního prŕíkopu reduty na 40-42 metry.

\section{Obj. 32, k. ú. Jaroměr - přesná lokalizace}

$\mathrm{Na} 1$. vojenském mapování je zakreslena reduta čtvercového půdorysu s osami ve směru sever-jih a východ-západ. Vchod do objektu byl v jeho severozápadním rohu. Reduta byla umístěna severně od cesty směřující z Jaroměře do Velichovek, na křižovatce této cesty s cestou směřující k jihu do Jezbin a další cesty směřující k severu do Hořenic (u odbočky na Hořenice je zakreslen kř́ižek). Nadzemní část objektu není dochována.

Cesta ve směru východ-západ na 2 . vojenském mapování se kryje se současným průběhem silnice, respektive ulice Dolecká. Odbočka na Hořenice s kř́ižkem. Objekt je zachycen na stabilním katastru z roku 1840 jako pravděpodobně zemědělsky obdělávaná zhruba čtvercová parcela č. 2071, obklopená neobdělávanou parcelou č. 2072 (W, tzn. Weiden = pastviny), která evidentně představuje prostor valového opevnění a zaneseného př́kopu. Majitelem parcely č. 2071 je v této době pan Wollanek z Josefova. Objekt se nacházel v okolí bodu 50²1'26.681"N, 1554'18.806"E, tedy západně od areálu současné nemocnice a východně od ulice Královédvorská. V současné době je prostor opevnění překryt městskou zástavbou.

\section{Obj. 33, k. ú. Jaroměr - přesná lokalizace}

Na 1. vojenském mapování je zakreslena luneta, hrotem směřující k severovýchodu. Objekt byl umístěn jižně od silnice vedoucí k České Skalici nad terénní hranou řeky Úpy. Kromě 1. vojenského mapování je zakreslena i na 2 . vojenském mapování a na stabilním katastru z roku 1840 (obr. 9). Tvar pozemku odpovídá podobě zachycené na vojenském mapování. Objekt se nacházel v okolí bodu $50^{\circ} 21^{\prime} 37.116^{\prime \prime} \mathrm{N}, 15^{\circ} 55^{\prime} 53.821^{\prime \prime E}$, v současnosti je tento prostor překryt městskou zástavbou.

\section{Obj. 34, k. ú. Jaroměř - přesná lokalizace}

Na 1. vojenském mapování je zakreslena reduta pětiúhelníkového půdorysu. Vstup do objektu byl z jeho západní strany. Objekt je zachycen i na 2. vojenském mapování a na stabilním katastru z roku 1840 je zaznamenán jako objekt vymezený zatravněným pozemkem (W - Weiden) v majetku K. K. Fortification (obr. 9). Toto opevnění bylo pravděpodobně zakresleno i na vedutě Jaroměře od J. Venuta z roku 1809 (obr. 10). Reduta byla situována západně od předešlého opevnění při levé (severní) straně hlavní silnice z Jaroměře na Českou Skalici. Během 20. století došlo k zastavění prostoru a nadzemní část objektu zanikla. Redutu můžeme lokalizovat do okolí bodu $50^{\circ} 21^{\prime} 38.791 " \mathrm{~N}, 15^{\circ} 55^{\prime} 46.715^{\prime \prime} \mathrm{E}$.

\section{Obj. 35, k. ú. Jaroměr - přesná lokalizace}

$\mathrm{Na} 1$. vojenském mapování je zakreslen redan s hrotem směřujícím k severovýchodu. Objekt byl vybudován v těsné blízkosti komunikace spojující cestu Jaroměř - Česká Skalice a Jaroměř - Heřmanice. Na 2. vojenském mapování je objekt zachycen pouze jako zalomení této cesty, ale zřetelně (jako zatravněná parcela v majetku K. K. Fortification) je zakreslen na stabilním katastru z roku 1840 (obr. 9). V současné době je prostor redanu zastavěn a jeho nadzemní části nejsou v terénu patrné. Objekt můžeme lokalizovat do okolí bodu 50²1'42.438"N, 1555'41.771"E.

\section{Obj. 36, k. ú. Jaroměr - přesná lokalizace}

Na 1. vojenském mapování je zakreslena reduta šestiúhelníkového půdorysu se vstupem na západní straně objektu. Opevnění je zakresleno na 2. vojenském mapování a na stabilním katastru z roku 1840 (obr. 9), zde opět jako prostor vymezený zatravněnou plochou (W - Weiden, v majetku K. K. Fortification). Fortifikace byla vybudována na křižovatce cest, nad jižní hranou Labské nivy. V současné době je prostor zčásti tvořen zahradami a polními pozemky, nadzemní části objektu nejsou v terénu patrné. Objekt se nacházel v okolí bodu 50²1'48.647"N, 155'3'36.981"E. 


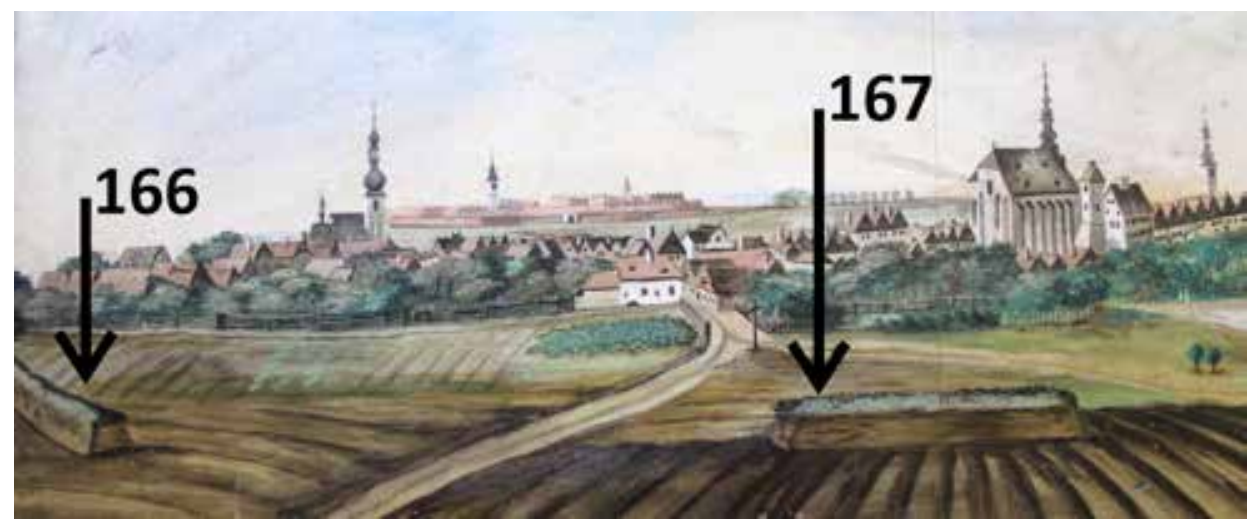

Obr. 11. Veduta Jaroměře od neznámého autora z 30. let 19. století, Městské muzeum v Jaroměři, inv. č. 5151. Objekty polních opevnění č. 166 a 167.

Abb. 11. Stadtansicht von Jaroměř von einem unbekannten Künstler aus den dreißiger Jahren des 19. Jahrhunderts, Stadtmuseum in Jaroměř, Inv.-Nr. 5151. Feldbefestigungsobjekte Nr. 166 und 167.
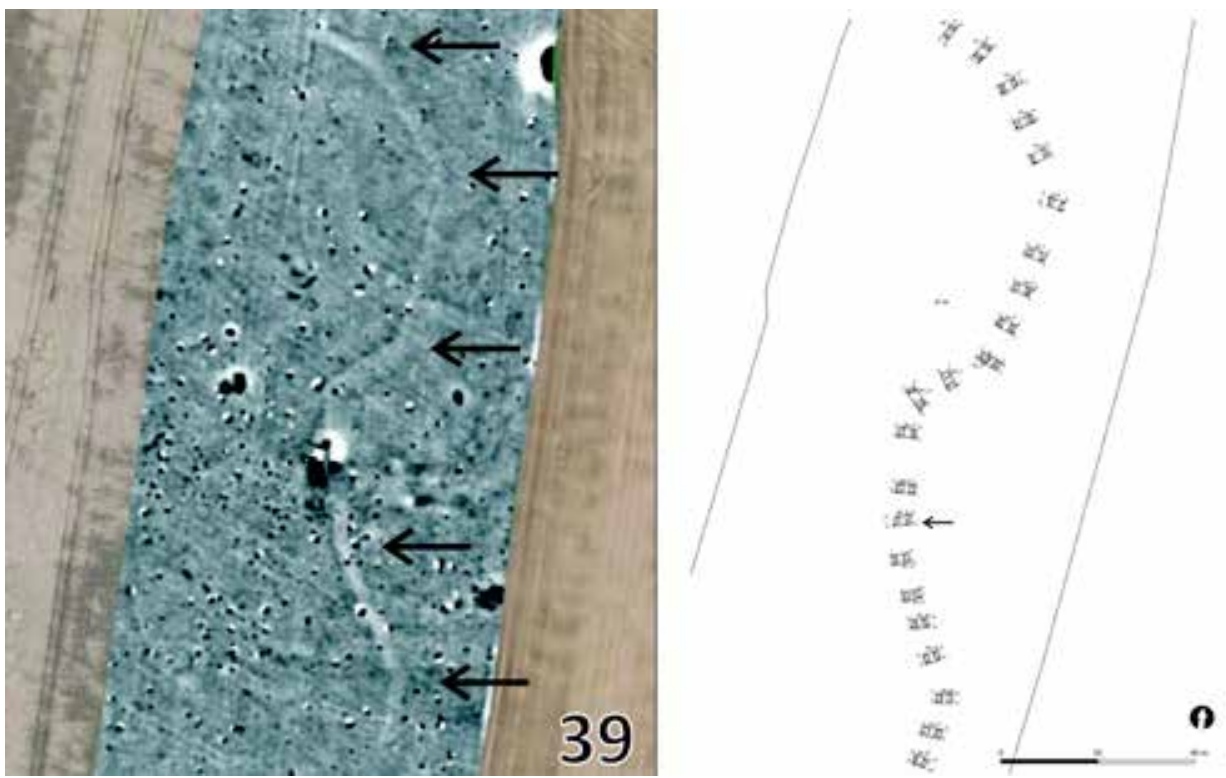

Obr. 12. Objekt polního opevnění č. 39 na k. ú. Hořenice. Vlevo výsledek magnetometrického průzkumu proběhlého na jaře roku 2017. Vpravo rozsah sondáže při záchranném archeologickém výzkumu na trase dálnice D11. Vedoucí výzkumu L. Rytír (AC Olomouc). Šipkou označen profil segmentu na obr. 13.

Abb. 12. Feldbefestigungsobjekt Nr. 39 im Katastergebiet Hořenice. Links das Ergebnis der im Frühjahr 2017 durchgeführten magnetometrischen Untersuchung. Rechts Umfang der während der Rettungsgrabung auf der Trasse der Autobahn D11 gelegten Sondierungsschnitte. Grabungsleiter L. Rytír (AC Olomouc). Mit einem Pfeil gekennzeichnet das Segmentprofil von Abb. 13.

Obj. 166 a 167 k. ú. Jaroměr - přesná lokalizace

$\mathrm{Na} 1$. vojenském mapování tyto objekty zakresleny nejsou. O jejich existenci svědčí ikonografické a kartografické prameny (dobové vojenské plány a stabilní katastr). Oba objekty jsou tvořené jednoduchým liniovým valem. Tyto valy jsou zachyceny na stabilním katastru z roku 
1840 jako W - Weiden v majetku K. K. Fortification in Josephstadt. Na existenci těchto objektů poukazuje i Albert Sasko-Těšínský, který ovšem zakresluje pouze jeden z nich. Oba valy jsou zakresleny na vedutě Jaroměře od anonymního autora z 30. let 19. století (obr. 11). Objekty byly vybudovány za polními opevněními č. 34-36 a tvořily druhou obrannou linii v tomto prostoru. V dnešní době se nachází pod souvislou zástavbou, nadzemní části objektů nejsou zachovány.

\section{Obj. 37, k. ú. Jaroměr $\check{r}$ - přsesná lokalizace}

$\mathrm{Na}$ 1. vojenském mapování je zakreslena luneta s hrotem směřujícím $\mathrm{k}$ severovýchodu. $\mathrm{Na} 2$. vojenském mapování není objekt zakreslen. Na stabilním katastru z roku 1840 je relikt opevnění zachycen jako zemědělsky neobdělávaná parcela č. $2146(\mathrm{~W}-$ Weiden = pastviny) v majetku K. K. Fortification. Nadzemní části opevnění nejsou dochovány. Luneta byla vybudována západně od silnice Jaroměř - Hořenice. Objekt lze klást do okolí bodu N 50²1.90062', E $15^{\circ} 54.26140$ ', tzn. plochy v současné době zastavěné.

\section{Obj. 38, k. ú. Hořenice - přesná lokalizace}

$\mathrm{Na} 1$. vojenském mapování je zakreslena luneta s hrotem směřujícím k severovýchodu. Na 2. vojenském mapování je v ploše jinak zemědělsky obdělávané půdy viditelná jako „zelená“ plocha. Na indikační skice stabilního katastru z roku 1840 je zachována jako parcela v majetku K. K. Fortification. Na císařském povinném otisku stabilního katastru je uvedena jako parcela č. 399, označeno W (Weiden = pastviny). Nadzemní části objektu nejsou dochovány. Luneta byla vybudována západně od silnice Jaroměř - Hořenice. Objekt se nacházel v okolí bodu $50^{\circ} 22^{\prime} 3.738^{\prime \prime} \mathrm{N}, 15^{\circ} 54^{\prime} 11.767 " \mathrm{E}$.

\section{Obj. 39, k. ú. Hořenice - přesná lokalizace}

Na 1. vojenském mapování je zakreslena luneta, ke které je na jižní straně připojen dvakrát zalomený liniový val. Hrot lunety směřuje k východu. Objekt je patrný také na 2 . vojenském mapování. Na indikační skice stabilního katastru z roku 1840 je plocha opevnění zachována jako parcela $\mathrm{v}$ majetku K. K. Fortifikation Josephstadt (obr. 14). Na císařském povinném otisku stabilního katastru je uvedena jako parcela č. 375, označeno W (Weiden = pastviny). Nadzemní části objektu se nedochovaly. Luneta byla archeologicky zkoumána roku 2017 v rámci záchranného výzkumu vyvolaného stavbou dálnice D11 (vedoucí výzkumu L. Rytír̆, Archelogické centrum Olomouc). V rámci př́pravy stavby byl objekt opevnění zaměřen magnetometrem (obr. 12). Luneta se nacházela v okolí bodu $50^{\circ} 22^{\prime} 18.724^{\prime \prime N}, 15^{\circ} 54^{\prime} 9.837 " \mathrm{E}$.

Celková délka objektu byla asi 149,5 m (měřeno př́ímkou od severního ramene lunety po jižní konec př́kopu), z toho jižní prŕíkopová line měřila zhruba $77,5 \mathrm{~m}$, respektive $71 \mathrm{~m}$ (měřeno prŕímkou od jižního konce lunety). Šiřka př́ikopu je 3-4 m a jeho hloubka kolísá v rozmezí $170-190 \mathrm{~cm}$. Př́íkop byl prozkoumán pomocí 22 sond, které rovnoměrně postihly všechny části opevnění. Charakter výplně př́ikopu nasvědčuje tomu, že luneta byla po svém opuštění zplanýrována, respektive př́íkop byl zaházen (obr. 13). Mezi nemnoha nálezy z prríkopu je několik zlomků novověké keramiky, zvířecí kosti a amorfní železné fragmenty.

\section{Obj. 40, k. ú. Hořenice - přesná lokalizace}

Na 1. vojenském mapování je zakreslena luneta s hrotem směřujícím k jihovýchodu. Objekt je umístěn na svahu západně od cesty Jaroměř - Hořenice. Objekt je zakreslen i na 2. vojenském mapování. Na indikační skice stabilního katastru z roku 1840 je opevnění zachováno v podobě parcely, dosud v majetku K. K. Fortifikation Josephstadt (obr. 14). Na císařském povinném otisku stabilního katastru je uvedena jako parcela č. 327, označeno W (Weiden = pastviny). Nadzemní části lunety nejsou dochovány. Objekt ležel v poloze Kamenec, popřípadě Na Kamenci, v okolí bodu $50^{\circ} 22^{\prime} 31.170 " \mathrm{~N}, 15^{\circ} 54^{\prime} 22.525^{\prime \prime} \mathrm{E}$. 

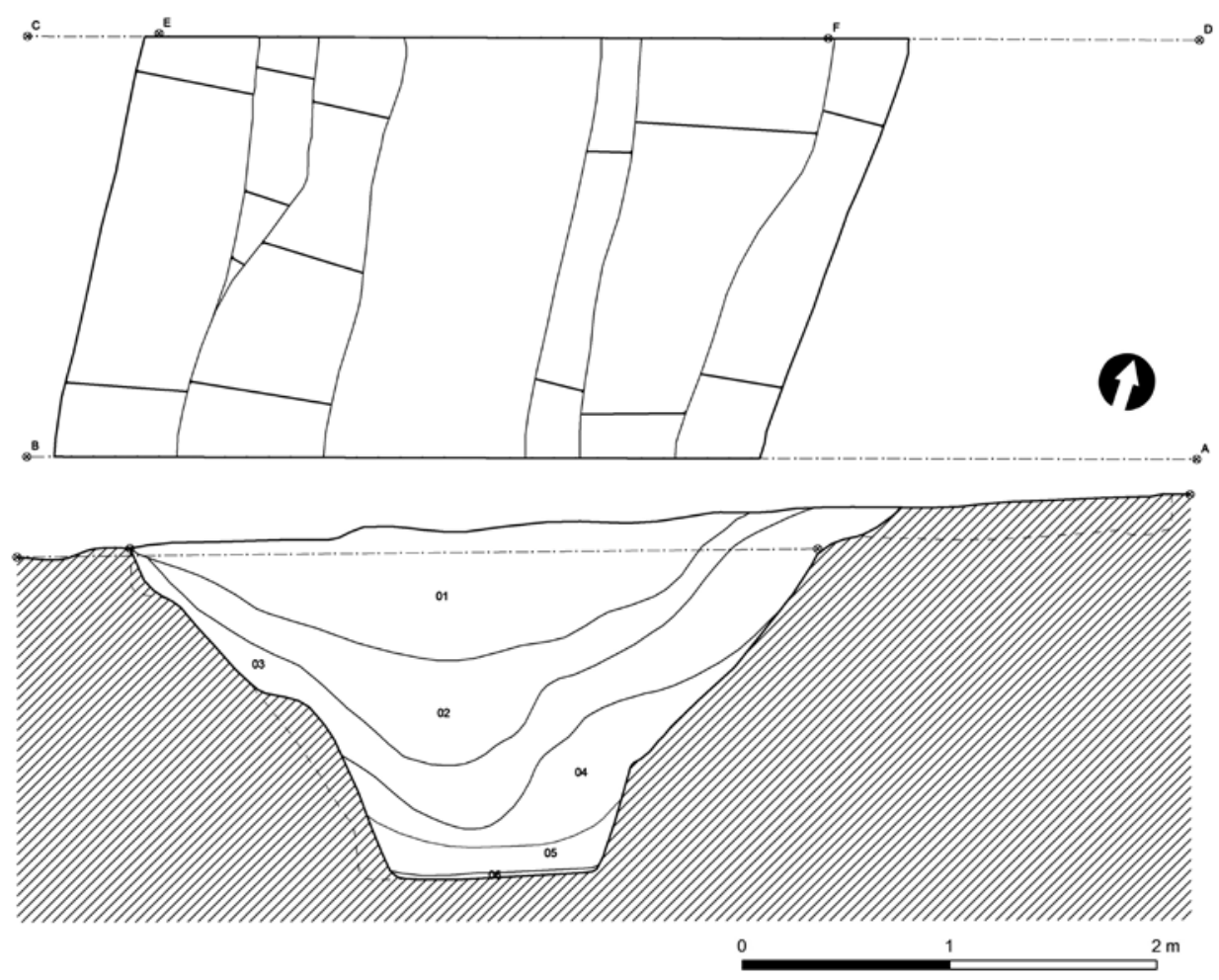

Obr. 13. Objekt polního opevnění č. 39 na k. ú. Hořenice. Profil segmentu 15. Vedoucí výzkumu L. Rytíř (AC Olomouc). Abb. 13. Feldbefestigungsobjekt Nr. 39 Im Katastergebiet Hořenice. Segmentprofil 15. Grabungsleiter L. Rytír (AC Olomouc).

Obj. 41, k.ú. Hořenice - přesná lokalizace

$\mathrm{Na}$ 1. vojenském mapování je zakreslen biret $\mathrm{s}$ hroty směřujícími k východu. Objekt je umístěn na svahu nad silnicí Jaroměř - Hořenice. Objekt je zakreslen na 2. vojenském mapování. $\mathrm{Na}$ indikační skice stabilního katastru z roku 1840 je plocha opevnění zachována jako parcela v majetku K. K. Fortifikation Josephstadt. Na císařském povinném otisku stabilního katastru je uvedena jako parcela č. 289, označeno W (Weiden = pastviny). Nadzemní části biretu se nedochovaly. Část objektu je viditelná na volně přístupném leteckém snímku z roku 2006. Objekt můžeme lokalizovat do okolí bodu 50²2'41.993"N, 1554'14.974"E.

Obj. 42, k. ú. Brod nad Labem - přibližná lokalizace

$\mathrm{Na} 1$. vojenském mapování je zakreslen redan s hrotem směřujícím $\mathrm{k}$ severovýchodu. Opevnění je vybudováno na návrší nad Heřmanicemi, jihozápadně od obce. Na 2. vojenském mapování ani na stabilním katastru objekt zachycen není. Nadzemní části redanu se nedochovaly. Polohu objektu můžeme klást do širšího okolí bodu 50²2'45.775"N, 1554'36.033"E.

Obj. 43, k. ú. Hořenice - přesná lokalizace

Na 1. vojenském mapování je zakreslena reduta s kosočtverečným půdorysem. Delší osa objektu je orientována ve směru severovýchod-jihozápad, vstup do objektu byl v jeho severozápadním rohu. Reduta byla vybudována na mírném svahu severozápadně od Heřmanic. Objekt je zakreslen na 2. vojenském mapování a na indikační skice stabilního katastru z roku 1840 je 


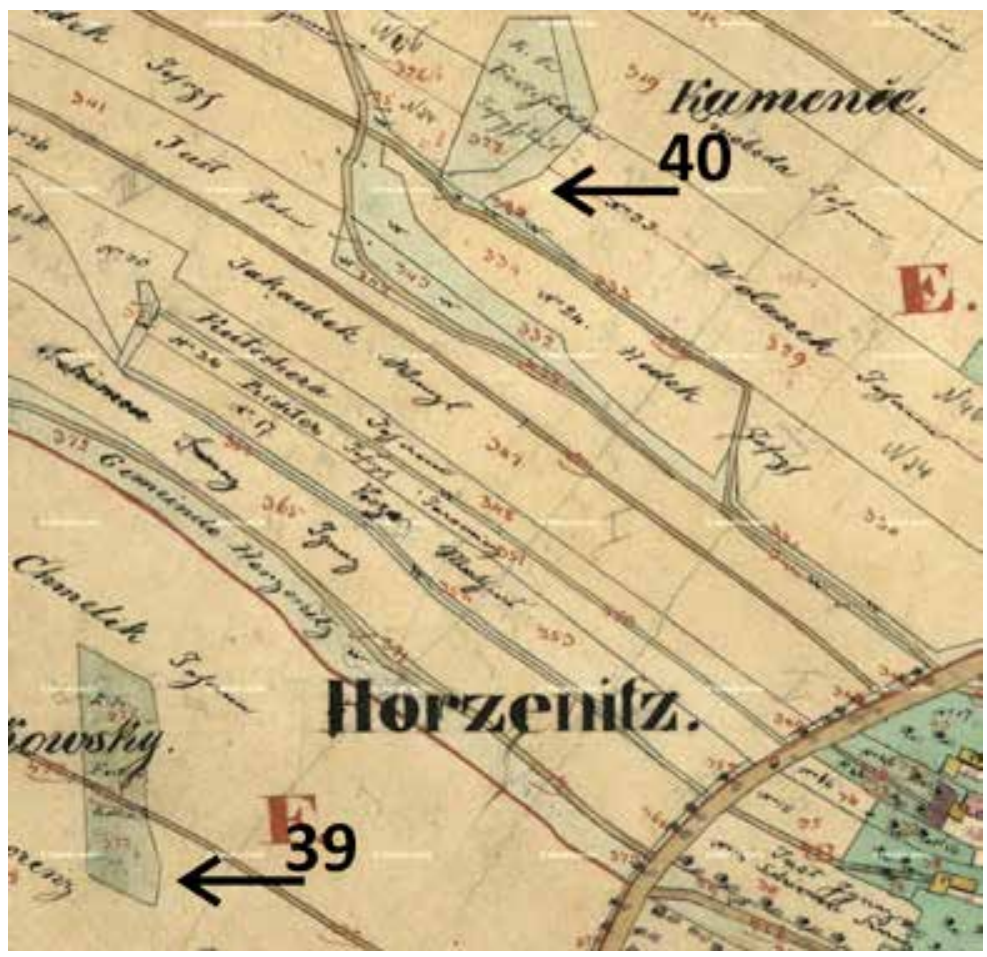

Obr. 14. Relikty objektů polních opevnění v prostoru na katastrálním území Hořenic zachycené na Indikační skice stabilního katastru, 1840. Zdroj https://archivnimapy.cuzk.cz; (C) ČUK.

Abb. 14. Feldbefestigungsobjekte im Bereich des Katastergebietes Hořenice dargestellt auf einer Indikationsskizze des stabilden Katasters, 1840. Quelle https://archivnimapy.cuzk.cz; (C) Tschechisches Amt für Landesvermessung und Kataster.

zachován jako parcela v majetku K. K. Fortifikation Josephstadt. Na císařském povinném otisku stabilního katastru je veden jako parcela č. 231, označeno $\mathrm{W}$ (Weiden = pastviny). Nadzemní části objektu se nedochovaly. Část reduty je viditelná na volně dostupných leteckých snímcích z let 2006 a 2015 (obr. 7; mapy.cz). Díky tomu je lokalizace objektu velmi přesná a můžeme ji klást do okolí bodu 50²2'53.478"N, 1554'16.334"E v poloze Láně, respektive Na Láni.

\section{Shrnutí}

Theodor Peters dělí Lacyho opevněnou linii z války o bavorské dědictví na horním Labi na pět skupin. Území, které je předmětem této studie, spadá do Petersovy skupiny ,die befestigte Linie Semonitz-Jaroměr-Kukus-Kaschow-Siebojed-Zales-Switschin" (Peters 1902, 318, 321-322). Ve sledované oblasti bylo v první polovině roku 1778 vybudováno (minimálně) dvacet objektů polních opevnění (objekty č. 26-43 a 166-167). Typologicky je můžeme rozdělit na dva liniové objekty, čtyři redany, dva birety, pět lunet a sedm redut (tabulka 1). Kromě liniových objektů 166 a 167 jsou všechny zakresleny na 1. vojenském mapování (existence těchto objektů je ale doložena jinými důvěryhodnými kartografickými prameny). Nelze vyloučit, že kromě zmíněných dvaceti objektů byly vybudovány ve sledované oblasti i objekty další. Tomu by nasvědčovaly například mapy v pamětech Alberta Sasko-Těšínského. V naší evidenci s nimi nepracujeme, nebot' jejich existenci v současné době nemáme doloženou jinými prameny. 
Jednoznačná a nepřekvapivá je prostorová vazba polních opevnění na pozemní komunikace, křižovatky a přechody přes vodní toky (obr. 6). Objekty č. 37-43 kontrolovaly cestu mezi Jaroměří a Hořenicemi, respektive cesty, které se od této hlavní komunikace oddělovaly a směřvaly na západ do vnitrozemí. Na východní břeh Labe je vysunuta skupina objektů v místech dnešního Jakubského předměstí. Tato opevnění přehrazovala prostor mezi Labem a Úpou a byla umístěna před terénní hranou nad nivami obou řek severovýchodně od centra města. Význam tohoto prostoru podtrhuje skutečnost, že linie čtyř objektů (č. 33-36) je zpevněna ještě druhou linií (objekty č. 166 a 167). Kromě cesty od České Skalice objekt č. 36 kontroloval i př́ípadný př́ístup po levém břehu Labe od Heřmanic. Objekty č. 26, 28 a 30 kromě cest kontrolovaly i mosty přes Jezbinský potok.

Vedle objektů polních opevnění můžeme v rámci Lacyho linie předpokládat i použití lehčích fortifikačních prvků, které nebyly zachyceny na 1. a 2. vojenském mapování ani na stabilním katastru. V první řadě se jedná o přeseky, které spojovaly jednotlivé opevněné objekty. Ty ve svých pamětech, mimo jiné v prostoru Jaroměře, zakreslil opět Albert Sasko-Těšínský. U těchto objektů je jejich archeologická doložitelnost již z principu problematická.

Archeologicky byl zkoumán objekt č. 39, luneta s liniovým valem, k. ú. Hořenice. Nadzemní části objektu nebyly dochovány, a výzkum se proto zaměřil na 22 řezů př́ikopem, které byly rovnoměrně položeny v celé jeho délce. Hloubka př́ikopu v podloží se pohybovala v rozmezí 170-190 cm. Ploché dno př́kopu bylo široké okolo $100 \mathrm{~cm}$, na úrovni skrývky byl příkop široký 370-380 cm. Pokud připočteme mocnost ornice, která v tomto prostoru kolísala okolo $20 \mathrm{~cm}$, můžeme předpokládat původní hloubku př́ikopu lunety okolo 2 metrů a šiřku okolo 4 metrů.

Výsledky výzkumu lze porovnat s výsledky výzkumů jiných objektů Lacyho linie. Roku 2013 byla $\mathrm{v}$ rámci záchranného archeologického výzkumu zachycena část prríkopu reduty z války o bavorské dědictví (objekt č. 12) na katastru Lochenice. Př́íkop měl v podstatě rovné stěny, které se svažovaly k rovnému plochému dnu. Maximální šiřka př́kopu na úrovni skrývky byla $460 \mathrm{~cm}$, maximální šířka dna byla $100 \mathrm{~cm}$ a v místě výzkumu dosahoval příkop hloubky $140 \mathrm{~cm}$ od úrovně skrývky (Hornik-Nácarová-Sybr-Burgert 2014). Další objekt polního opevnění z války o bavorské dědictví byl pravděpodobně zachycen při archeologických výzkumech spojených se stavbou vodojemu na katastru Holohlavy v letech 1971 a 1976. Na profilech liniových výkopů byl dokumentován př́íkop se šikmými stěnami, hluboký $120 \mathrm{~cm}$. Objekt byl na základě keramiky z výplně datován do období lužické kultury. Interpretace lokality byla již v době publikace výzkumu vnímána jako neobvyklá: „Jde-li skutečně o přikop, potom takto ohrazená a opevněná rovinná osada nemá ve východočeské oblasti lidu popelnicových poli analogii““ (Vokolek 1985, 54). Nelze vyloučit možnost, že se jedná o př́ikop lunety Lacyho systému (obj. č. 17), která se v tomto prostoru nacházela. Přítomnost pravěkých nálezů v novověkém objektu lze vysvětlit existencí sídliště lužické kultury, které stavba polního opevnění narušila (HejhalHornik 2017, 213-214).

Válka o bavorské dědictví byla ukončena podepsáním těšínského míru 13. května 1779. Objekty polních opevnění východočeské části Lacyho linie zůstaly vyzbrojeny děly i v následujících letech. Teprve od února do dubna roku 1782 byla na rozkaz císaře Josefa II. děla z polních opevnění stahována. Děla z pevností mezi Dvorem Králové a Vrchlabím byla shromážděna u Mnichova Hradiště, 120 děl tvořících výzbroj polních opevnění u Jaroměře, Kuksu a Dvora Králové bylo umístěno v rozestavěné josefovské pevnosti (Duška 1886, 107-108). S udržováním bojeschopného stavu polních opevnění Lacyho linie koresponduje i nařízení o zákazu poškozování palisád na opevnění Tři Bubny u Chrudimi, také z roku 1782 (Florián 1926, 58).

\section{Závěr}

Ve sledované oblasti na soutoku řek Labe, Metuje a Úpy bylo v souvislosti s válkou o bavorské dědictví vybudováno (minimálně) dvacet objektů polních opevnění. Na základě kombinace analýzy mapových podkladů, veřejně dostupných leteckých snímků, geofyzikálních měření a archeologických výzkumů jsme je schopni více či méně přesně lokalizovat všechny. Objekty 
polních opevnění byly budovány u pozemních komunikací, jejich křižovatek a míst, kde cesty překračovaly vodní toky.

Do dnešní doby zůstaly zachovány nadzemní části u dvou objektů (č. 27 a č. 29), což je $\mathrm{v}$ prostředí intenzivně zemědělsky obdělávané krajiny poměrně výjimečná situace. K dochování těchto objektů došlo z toho důvodu, že byly začleněny do infrastruktury nově budované pevnosti Ples/Josefov a byly do nich umístěny budovy mírových pracháren. Celkem čtrnáct z dvaceti objektů se dochovalo v terénu ještě v době tvorby stabilního katastru a 2 . vojenského mapování v 19. století.

U objektů ve volné krajině je vysoká pravděpodobnost upřesnění jejich polohy a půdorysu pomocí cíleného geofyzikálního měření, případně jiných metod. Ověření objektů, které se nacházejí v současné zástavbě, je problematické, respektive odkázané na prŕípadné archeologické výzkumy nejpravděpodobněji záchranného charakteru.

Již dnes víme, že některé z objektů jsou bezprostředně ohroženy plánovanými stavbami. Jedná se v první řadě o objekty č. 41 (biret) a 43 (reduta), které podle v současné době dostupných informací leží v těsné blízkosti trasy plánované dálnice D11 či přímo na ní. V době přípravy stavby bude nutné s touto skutečností počítat.

\section{Literatura}

ČÍŽEK, J.-SLAVÍK, J., 2010: Zemní opevnění z 18. století ve východních Čechách. In: Polní opevnění od třicetileté války do roku 1945, 37-44. Jaroměř - Josefov.

DRNOVSKÝ, P.-HEJHAL, P., 2018: Krajina k boji odsouzená. Polní tábor pruského krále Fridricha II. ze srpna 1778 pohledem archeologie - Landscape Condemned to Battle. The field camp of the Prussian king Fridrich II from the August 1778 from an archaeological point of view, Živá archeologie REA 19/2017, 42-51.

- v tisku: Př́́klady dokumentace polních opevnění z války o bavorské dědictví (1778-1779).

DUFFY, Ch., 1985: Frederick the Great: A Military Life. London.

DUŠKA, J., 1886: Paměti c. k. pevnosti a královského svobodného města Josefova, se zřetelem k dějinám vlasti a vojenství. Jaroměr̆.

FLORIÁN, Č., 1926: Tři Bubny, Vlastivědný sborník východočeský III, 52-59.

HEJHAL, P.-HORNIK, P., 2017: Polní opevnění z války o bavorské dědictví mezi Třemi Bubny a Jaroměŕi - Field fortifications from the time of the War of the Bavarian Succession between Tři Bubny and Jaroměr̆, AVČ 10, 207-230.

HONL, I., 1924: Lloydův návrh systematického opevnění severních českých hranic v r. 1766, Důstojnické listy 4,385 .

- 1924a: Obranný úsek na horním Labi a jeho význam v pruských válkách, Vojenské rozhledy 10, 533-538.

- 1925-1926: Zimní boje na Broumovsku, Od kladského pomezí III, 17-22, 46-48, 59-61.

HORNIK, P.-NÁCAROVÁ, J.-SYBR, P.-BURGERT, P., 2014: Úprava křižovatky I/33 a III/32531 Trotina. Nálezová zpráva, ulož. v Muzeu východních Čech v Hradci Králové.

HOSÁK, L., 1964: Válečná kampaň v létě 1745 v Podkrkonoší a bitva u Zárova, Krkonoše-Podkrkonoší 1, $71-85$.

IŠA, F., 2006: Pruská topografická a vojenská mapa tažení 1778 v severovýchodních Čechách z roku 1789; interpretace mapy území mezi Krkonošemi a Kladskem z pera pruského kartografa Friedricha Wilhelma Carla von Schmettau. Rkp. bakalářské práce, ulož. na FF UHK, vedoucí práce Eva Semotanová. Trutnov - Hradec Králové.

KNNAP, A., 1887: Paměti královského věnného města Jaroměře nad Labem. Jaroměr̆.

MAUR, E., 2003: 12. 5. 1743 Marie Terezie. Korunovace na usmířenou. Praha.

MERTLÍKOVÁ, O.-Č́IZŽEK, J., 2004: Důsledky válečných událostí na vývoj Jaroměře v období třicetileté války. In: Věnná města za třicetileté války a jejich poválečná obnova. Sborník př́ispěvků z konference konané ve dnech 4.-5. května 2004 (Kilián, J., ed.), 101-110. Mělník.

MIKULKA, J., 1994: Dějiny Hradce Králové II/2. Hradec Králové.

NEJMAN, M., 2010: Popis lokalit s polními fortifikacemi na severním bojišti války o bavorské dědictví. In: Polní opevnění od trricetileté války po rok 1945, 45-59. Jaroměř - Josefov.

PETERS, T., 1902: Die österreichische Befestigungen an der oberen Elbe. In: Mitteilungen des K. u. K. Kriegsarchives, 291-295. Wien. 
SCHMETTAU, F. W. C., 1789: Über den Feldzug der Preussischen Armee in Böhmen im Jahre 1778. Berlin. SLAVÍK, J., 2016: Královéhradecká pevnost. Hradec Králové.

STELLNER, F., 2000: Sedmiletá válka v Evropě. Praha.

ŠEDIVÝ, J., 2018: O švestky a brambory. Prusko-rakouská válka o bavorské dědictví 1778-1779. Praha.

VESELÝ, A., ed., 2018: Jan Antonín Venuto a jeho dílo. Praha.

VOJTÍŠKOVÁ, J.-POLEHLA, P., 2017: Město v době tereziánských a josefinských reforem (1740-1790). In:

Hradec Králové (Zahradník, Z., ed.), 268-312. Praha.

VOKOLEK, V., 1985: Nálezy při stavbě vodojemu v Holohlavech, Zpravodaj Krajského muzea východních Čech v Hradci Králové XII, č. 1, 40-64.

ŽÁKOVSKÝ, P.-DRNOVSKÝ, P., 2017: Nález barokního kordu z Habřiny na Jaroměřsku ve východních Čechách - Der Fund des Barockdegens aus Habřina in der ostböhmischen Region Jaroměr̆, AH 42, 279-295.

\section{Zusammenfassung}

Feldbefestigungen bei Jaroměř während des bayerischen Erbfolgekriegs (1778-1779). Die Verteidigung des strategisch gelegenen Raumes am Zusammenfluss der Elbe, Mettau und Aupa vor dem Bau der Festung Ples/Josefstadt

Der in den Jahren 1778 und 1779 erfolgte bayerische Erbfolgekrieg brachte einen bis dahin in der Habsburger Monarchie nie dagewesenen Einsatz an Feldbefestigungen mit sich, die gegen die Angriffe der sächsisch-preußischen Armeen in Nord- und Ostböhmen angelegt worden waren. Im Rahmen der Befestigungslinie nahm das Gebiet um Jaroměř als gedachter nordöstlicher Eingang zum Elbgebiet eine Sonderstellung ein. Die militärische Bedeutung dieses Raumes wurde im Jahr 1780 durch die Grundsteinlegung der neuen Festung Ples/Josefstadt bestätigt.

Im beobachteten Gebiet wurden am Zusammenfluss der Elbe, Mettau und Aupa im Zusammenhang mit dem bayerischen Erbfolgekrieg (mindestens) zwanzig Feldbefestigungsobjekte angelegt. Anhand einer Kombination der Analyse der Kartenunterlagen mit öffentlich zugänglichen Luftaufnahmen, geophysikalischen Vermessungen und archäologischen Grabungen sind wir dazu in der Lage, alle mehr oder weniger genau zu lokalisieren. Die Feldbefestigungsobjekte wurden an Landverkehrswegen, ihren Kreuzungen und an Orten angelegt, an denen die Wege Wasserläufe überquerten.

Bis heute sind die oberirdischen Teile von zwei Objekten erhalten geblieben (Nr. 27 und Nr. 29), was in einer landschaftlichen Umgebung mit intensiver Feldbewirtschaftung eine ziemlich außergewöhnliche Situation ist. Zur Erhaltung dieser Objekte ist es deswegen gekommen, weil man sie in die Infrastruktur der neu angelegten Festung Ples/Josesfstadt eingegliedert hat und in ihnen die Gebäude von Pulvermagazinen untergebracht wurden. Insgesamt vierzehn von zwanzig Objekten waren noch bis in die Zeit des stabilen Katasters und der 2. militärischen Kartierung im 19. Jahrhundert im Gelände erhalten geblieben.

Bei den Objekten in der freien Landschaft besteht eine hohe Wahrscheinlichkeit, ihre Lage und ihren Grundriss mithilfe einer gezielten geophysikalischen Vermessung, ggf. mit anderen Methoden zu präzisieren. Eine Überprüfung der Objekte, die sich in der heutigen Bebauung befinden, gestaltet sich problematisch, bzw. ist auf eventuelle archäologische Grabungen mit höchtswahrscheinlich Rettungsgrabungscharakter angewiesen.

Wir wissen heute schon, dass einige Objekte von sich in Planung befindlichen Bauten unmittelbar bedroht sind. Bei ihnen handelt es sich in erster Linie um die Objekte Nr. 41 (Flesche) und 43 (Redoute), die den zur Zeit verfügbaren Informationen nach in dichter Nähe zur Trasse der geplanten Autobahn D11 oder unmittelbar auf ihr liegen. Während den Vorbereitungsarbeiten zu dem Autobahnbau muss mit dieser Tatsache gerechnet werden. 
Pavel Drnovský, Katedra archeologie Filozofické fakulty Univerzity Hradec Králové, Rokitanského 62, 50003 Hradec Králové, Česká republika, pavel.drnovsky@uhk.cz

Petr Hejhal, Katedra archeologie Filozofické fakulty Univerzity Hradec Králové, Rokitanského 62, 50003 Hradec Králové, Česká republika, petr.hejhal.2@uhk.cz

Ladislav Rytír, Katedra archeologie Filozofické fakulty Univerzity Hradec Králové, Rokitanského 62, 50003 Hradec Králové, Česká republika, ladislav.rytir@uhk.cz 
